\title{
PERUMUSAN STRATEGI PEMASARAN FRY COUNTER DENGAN PENDEKATAN MODEL AIDA
}

\author{
Andi Oktoriyana ${ }^{1,2^{*}}$, Ujang Sumarwan ${ }^{3}$, Hartoyo $^{3}$ \\ ${ }^{1}$ PT Carsurin, Jakarta Barat 11410, Indonesia \\ ${ }^{2}$ Program Studi Manajemen Bisnis, Institut Pertanian Bogor, Bogor 16151, Indonesia \\ ${ }^{3}$ Departemen Ilmu Keluarga dan Konsumen, Fakultas Ekologi Manusia, Institut Pertanian Bogor, \\ Bogor 16680, Indonesia \\ *)E-mail: andi.okto@yahoo.com
}

\begin{abstract}
Abstrak
Penelitian ini menguji faktor-faktor yang telah dijelaskan pada beberapa literatur yang memiliki pengaruh terhadap model AIDA untuk pembelian fry counter; yaitu kesadaran, ketertarikan, dan minat. Model tersebut juga dipengaruhi oleh persepsi konsumen terhadap atribut produk, faktor pribadi, dan lingkungan. Lebih lanjut, hasil analisis akan dijadikan landasan dalam merumuskan strategi pemasaran fry counter sebagai sebuah produk inovatif. Data yang digunakan dalam penelitian ini diperoleh dari hasil wawancara dengan 152 responden yang merupakan pembudidaya ikan di Kabupaten Sukabumi, Provinsi Jawa Barat. Data yang telah dikumpulkan dianalisis dengan menggunakan Structural Equation Modeling (SEM). Penelitian ini menemukan bahwa faktor lingkungan dan pribadi memiliki pengaruh positif terhadap persepsi atribut. Faktor lingkungan dan persepsi atribut memiliki pengaruh positif terhadap kesadaran. Faktor lingkungan memiliki pengaruh negatif namun pribadi dan kesadaran memiliki pengaruh positif terhadap ketertarikan. Faktor persepsi atribut dan ketertarikan memiliki pengaruh positif terhadap faktor minat. Implikasi manajerial dirumuskan dalam pembahasan ini.
\end{abstract}

Kata kunci: fry counter, model AIDA, SEM, strategi pemasaran

\section{Marketing Strategy Formulation Fry counter with AIDA Model Approach}

\begin{abstract}
This research examined factors which are mentioned in various literatures that have influence on AIDA models to buy fry counter which are attention, interest, and desire. The model also influenced by perceived attributes, personal characteristics, and external factors. Furthermore, the analysis result become a basic for formulating the marketing strategy of fry counter as an innovative product. Analysis was carried out using Structural Equation Modeling. The data for this study were collected from 152 respondents who were fish farmers located in Sukabumi Regency, West Java Province. This research found that external and internal factors influenced positively perceived attributes faktors. The external and perceived attributes factors also influenced positively attention factor. The external factor had negative influence but internal and attention factors had positive influence on consumer's interest. Perceived attributes and interest factors influenced positively desire factor. Managerial implications is elaborated in the discussion.
\end{abstract}

Keywords: AIDA model, fry counter, marketing strategy, SEM

\section{PENDAHULUAN}

Dalam perikanan budidaya terdapat beberapa subusaha yang meliputi usaha pembenihan, pendederan, sampai dengan proses pembesaran. Usaha pembenihan merupakan rantai awal dari siklus budidaya ikan. Penyediaan benih unggul merupakan faktor kunci dan strategis untuk dapat menggerakkan seluruh sumber daya dan potensi perikanan budidaya sehingga mampu berkontribusi terhadap pembangunan nasional. Pada umumnya benih yang dihasilkan di sektor perikanan memiliki ukuran yang sangat kecil dan jumlah- nya sangat banyak. Pengusahaan benih ikan oleh para pembenih ikan seringkali menemui kendala terkait dengan jumlah benih yang diproduksinya. Saat ini belum ada teknologi yang membantu para pembenih ikan dalam melakukan penghitungan benih secara lebih cepat. Penghitungan benih secara manual oleh pembenih ikan membutuhkan waktu yang lama dan bisa mencapai waktu satu hingga dua hari untuk 50 ribu ekor yang dihitung dengan menggunakan tenaga kerja 3-4 orang dan ratarata kerja 5 jam/hari. Jumlah benih yang biasanya diproduksi oleh pembenih ikan sering- 
kali lebih dari 50 ribu ekor (Jaya \& Rahmat, 2012).

Peranan teknologi baik sederhana maupun modern untuk budidaya perikanan harus dilakukan secara simultan dan berkesinambungan sehingga seluruh aspek produksi hingga pemasaran perikanan dapat menunjang perekonomian nasional. Institut Pertanian Bogor (IPB) sebagai salah satu perguruan tinggi melakukan inovasi-inovasi melalui penelitian yang dilakukan oleh tiap-tiap departemen. Departemen IImu dan Teknologi Kelautan Fakultas Perikanan dan IImu Kelautan berupaya untuk memberikan solusi dalam penghitungan benih melalui inovasi produk fry counter (penghitung benih). Fry counter merupakan suatu alat penghitung benih berkecepatan tinggi dengan akurasi yang tinggi. Penggunaan fry counter dapat menjadikan proses penghitungan benih menjadi lebih efisien baik secara waktu maupun finansial. Proses penghitungan dengan fry counter lebih cepat dibandingkan dengan metode manual dan penggunaan metode ini juga dapat menghemat jumlah tenaga kerja. Selain membantu para pembenih benih ikan, alat ini juga dapat membantu pembeli benih untuk mendapatkan jumlah benih yang akurat dan potensi stres pada benih ikan menjadi berkurang.

Sebagai sebuah produk baru hasil inovasi yang akan dipasarkan secara luas dan diproduksi masal, salah satu pendekatan yang bisa dilakukan dalam memberikan pertimbangan ilmiah dan empiris dalam pemasaran produk fry counter adalah pendekatan adopsi inovasi. Soleh (2008) menyatakan bahwa adopsi konsumen adalah suatu proses yang secara tradisional dikonseptualisasikan sebagai suatu tahapan dimana konsumen melewati tahap dari pengetahuan awal dari suatu inovasi ke pembentukan sikap terhadap inovasi tersebut hingga mencapai keputusan adopsi. Penelitian tentang adopsi inovasi di Indonesia masih sangat sedikit tetapi terdapat beberapa penelitian seperti yang dilakukan oleh Chaudhuri (1994) mengenai minyak goreng dan minyak dari minyak sawit di Indonesia. Hasil tersebut menunjukkan bahwa karakteristik inovasi produk dan penggunaan agen perubahan sangat dominan dalam kesuksesan adopsi di Indonesia. Adapun penelitian oleh Sandee dan Rietveld (2001) yang meneliti adopsi teknologi pada pembuatan genteng tradisional di Indonesia juga menemukan bahwa perubahan teknologi bukan hanya mengenai perbandingan biaya dan manfaat dari suatu teknologi, tetapi juga mengenai akses terhadap teknologi tersebut dan juga akses terhadap modal dan sumberdaya lainnya yang dibutuhkan. Rahab (2009) dalam penelitiannya mengenai adopsi teknologi informasi di Yogyakarta menemukan bahwa keuntungan relatif memiliki pengaruh positif pada adopsi teknologi informasi. Temuan-temuan tersebut menegaskan bahwa dalam proses adopsi sebuah inovasi terdapat berbagai faktor yang memengaruhi mulai dari karakteristik produk itu sendiri, karakteristik konsumen, maupun faktor di luar produk dan konsumen.

Dalam sebuah proses adopsi inovasi produk baru, upaya terbesar yang dapat dilakukan oleh produsen fry counter adalah mengupayakan pemasaran yang dapat membangkitkan minat konsumen yang selanjutnya akan memengaruhi keputusan untuk membeli atau tidak produk fry counter. pemasaran minat adalah faktor penting yang memengaruhi keputusan pembelian (Sumarwan, 2011). Salah satu pendekatan yang dapat digunakan untuk menjelaskan faktor-faktor yang dapat memengaruhi minat konsumen terhadap produk baruadalah model AIDA. Model AIDA dibangun dari empat komponen utama, yaitu Attention (kesadaran), Interest (ketertarikan), Desire (minat), dan Action (tindakan) yang biasanya digunakan untuk mengukur efektivitas produk baru (Kotler \& Armstrong, 2008). Oleh karenanya, sebagai sebuah produk baru yang akan dipasarkan luas perlu dianalisis terlebih dahulu minat (Desire) konsumen dalam membeli fry counter. Pendekatan AIDA dapat menjelaskan minat pembelian konsumen terhadap produk fry counter melalui tahapan dari tingkat kesadaran (Attention) dan ketertarikan (Interest). Sebagai sebuah produk baru yang akan dipasarkan maka penelitian ini membatasi ruang lingkup analisis hanya sampai pada tahap minat (Desire) dan tidak sampai pada tindakan pembelian (Action).

Faktor yang berpengaruh terhadap tahapan AIDA yaitu faktor lingkungan yang merupakan berbagai faktor diluar konsumen seperti saluran komunikasi (Martinez, Polo, \& Flavián, 1998; Pitt, Napoli, \& Van Der, 2003), faktor keluarga dan teman (Azizi \& Hikmah, 2008), maupun interaksi sosial (Santosa, 2006). Selain itu, juga terdapat faktor lain yang juga berpengaruh seperti perbedaan individu (konsumen). Faktor yang berasal dari masingmasing konsumen tersebut berupa sumber daya konsumen, motivasi, pengetahuan, sikap, maupun kepribadian. Faktor perbedaan individu dapat berpengaruh langsung pada minat 
membeli fry counter namun dapat juga melalui tahap kesadaran dan ketertarikan. Berdasarkan hal tersebut maka persepsi atribut, faktor lingkungan, perbedaan individu, dan tahapan mulai dari kesadaran serta ketertarikan akan membentuk keterkaitan dalam menjelaskan minat membeli fry counter secara komprehensif.

Dengan menganalisis menggunakan model AIDA, dapat dirumuskan suatu strategi pemasaran yang komprehensif dengan mempertimbangkan variabel yang diteliti sehingga dapat diaplikasikan langsung ketika fry counter sudah benar-benar siap diproduksi dan dipasarkan secara masal. Berdasarkan pemaparan tersebut, penelitian ini bertujuan untuk menganalisis pengaruh faktor pribadi dan lingkungan serta persepsi atribut terhadap tahapan kesadaran, ketertarikan, dan minat pembenih ikan untuk mengadopsi fry counter. Berdasarkan analisis tersebut maka artikel ini juga akan merumuskan strategi pemasaran yang tepat untuk memaksimalkan penggunaan fry counter sebagai produk inovatif bagi para petani pembenih ikan.

\section{METODE}

Penelitian dilakukan dengan menggunakan desain cross sectional. Penelitian ini dilakukan pada bulan Juni sampai dengan November 2013 dengan mengambil responden pembudidaya benih ikan di Kabupaten Sukabumi, Provinsi Jawa Barat. Pemilihan lokasi penelitian dilakukan secara sengaja (purposive) dengan pertimbangan Sukabumi merupakan salah satu sentra benih ikan yang meliputi ikan konsumsi maupun ikan hias. Selain itu, di Sukabumi terdapat Balai Besar Pengembangan Budidaya Air Tawar (BBPBAT) yang memiliki kemitraan yang erat dengan pembudidaya ikan.

Responden dalam penelitian ini adalah pembudidaya benih ikan. Kriteria responden adalah berusia minimal 18 tahun, boleh berstatus sebagai pemilik, pemilik dan pengelola, atau pengelola usaha budidaya benih ikan, dengan pengalaman usaha lebih dari 1 tahun. Pengambilan contoh dilakukan dengan menggunakan teknik pengambilan contoh tak berpeluang (nonprobability sampling technique). Adapun cara pemilihan contoh yang menjadi responden dalam penelitian ini adalah secara convenience sampling. Penentuan rentang umur didasarkan atas asumsi bahwa pada rentang usia tersebut responden berpeluang untuk mengelola/memiliki usaha pembenihan dan mempunyai otonomi untuk melakukan keputusan terkait usaha yang dijalankan/dimilikinya. Responden yang dipilih berjumlah 152 orang.

Data primer meliputi demografi dan gambaran usaha, persepsi atribut, dan minat konsumen. Data ini diperoleh melalui wawancara dengan menggunakan instrumen kuesioner kepada contoh penelitian. Pengukuran masing-masing pernyataan yang digunakan dalam kuesioner penelitian diukur menggunakan skala jawaban Likert yaitu sangat tidak setuju (skor 1), tidak setuju (skor 2), biasa saja (skor 3), setuju (skor 4), dan sangat setuju (skor 5). Instrumen yang digunakan untuk mengukur variabel persepsi atribut, variabel lingkungan, variabel pribadi, dan variabel minat pembelian telah reliabel dengan nilai Cronbach's alpha lebih besar dari 0,6 .

Pengukuran persepsi konsumen terhadap atribut-atribut fry counter perlu dilakukan karena akan menjadi bahan pertimbangan bagi konsumen apabila akan membeli ataupun menggunakannya. Unsur-unsur dalam persepsi atribut produk fry counter terdiri atas: (1) keunggulan relatif (merujuk pada keunggulan fry counter dibandingkan dengan cara konvensional menghitung benih dari sisi kehandalan dan tenaga kerja), (2) kesesuaian (kecocokan fry counter dalam penggunaan dan kebiasaan sehari-hari), (3) kerumitan (derajat kerumitan dari fry counter baik dalam penggunaan dan perawatannya), (4) mampu coba (kemampuan produk untuk dicoba yang menunjukkan cara pemakaian maupun kehandalannya), dan (5) mampu observasi (kemudahan untuk memahami manfaat dari fry counter dan kemudahan untuk menjelaskan kepada orang lain). Masing-masing atribut memiliki dua indikator sehingga seluruh indikator untuk menjelaskan atribut-atribut fry counter berjumlah sepuluh.

Selain atribut produk, faktor lingkungan merupakan faktor di luar konsumen yang dapat memengaruhi tahapan kesadaran, minat, dan keinginan. Indikator lingkungan ini dapat berupa saluran komunikasi dan pengaruh lingkungan sosial dari keluarga, teman, organisasi, dan media massa. Lingkungan dalam penelitian ini diukur dalam empat indikator. Sementara itu, faktor pribadi merupakan faktor dari masingmasing konsumen yang dapat memengaruhi tahapan kesadaran, minat, dan keinginan. Faktor yang berasal dari masing-masing konsumen tersebut berupa sumber daya konsumen, motivasi, pengetahuan, sikap, maupun kepribadian. 

Pendekatan model AIDA akan digunakan untuk tahapan kesadaran, ketertarikan, hingga minat dalam membeli fry counter. Kesadaran (attention) merujuk pada kesadaran konsumen tentang keberadaan dari produk. Ketertarikan (interest) merujuk pada ketertarikan konsumen pada produk baik dari fitur maupun manfaat penggunaan fry counter. Minat (desire) merupakan keyakinan konsumen bahwa konsumen menginginkan dan berminat terhadap produk fry counter untuk memenuhi kebutuhannya. Dalam penelitian ini, pengukuran kesadaran menggunakan dua indikator serta ketertarikan dan minat masing-masing lima indikator.

Data dalam penelitian ini dianalisis secara deskriptif dan Structural Equation Modeling (SEM). Analisis deskriptif berfungsi memberkan gambaran mengenai karakteristik umum konsumen berdasarkan demografi, keterangan usaha, maupun indeks pangsa pasar. Sementara itu, analisis SEM digunakan untuk menganalisis faktor-faktor yang memengaruhi strategi pemasaran fry counter dengan menggunakan model AIDA.

Beberapa ukuran kriteria kesesuaian keseluruhan model yang dibahas dalam penelitian ini adalah parameter Chi-square, Probability (p-value), Goodness of Fit Index (GFI), Comparative Fit Index (CFI), Root Mean Square Residual (RMR), dan Root Mean Square Error of Approximation (RMSEA). Hasil kriteria kesesuaian keseluruhan model SEM yang digunakan dalam penelitian ini dapat dilihat pada Tabel 1.

Berdasarkan nilai yang didapat, keseluruhan model yang dibangun memiliki nilai yang sesuai sehingga model yang dibangun dapat menjelaskan informasi empiris sesuai data yang dikumpulkan. Walaupun ukuran kesesuaian GFI dan CFI berada dalam kategori marginal fit, ukuran kesesuaian Chi-Square/df, RMR, dan RMSEA sudah berada dalam kategori good fit.

Tabel 1 Hasil kriteria kesesuaian keseluruhan model Structural Equation Modeling (SEM)

\begin{tabular}{llrc}
\hline \multicolumn{1}{c}{$\begin{array}{c}\text { Ukuran } \\
\text { Kesesuaian }\end{array}$} & $\begin{array}{c}\text { Cut off } \\
\text { Value }\end{array}$ & $\begin{array}{c}\text { Hasil } \\
\text { Penelitian }\end{array}$ & Keterangan \\
\hline $\begin{array}{l}\text { Chi- } \\
\text { Square/df }\end{array}$ & $\leq 3,00$ & 2,13 & Good fit \\
GFI & & & \\
CFI & $\geq 0.90$ & 0,83 & Marginal fit \\
RMR & $\geq 0,90$ & 0,87 & Marginal fit \\
RMSEA & $\leq 0,05$ & 0,01 & Good fit \\
\hline
\end{tabular}

\section{HASIL}

\section{Karakteristik Responden}

Menurut Sumarwan (2011) demografi akan mengambarkan suatu karakteristik dari konsumen suatu produk. Karakteristik demografi yang dianalisis pada penelitian ini meliputi usia, jenis kelamin, status pernikahan, jumlah anggota keluarga, tingkat pendidikan terakhir, pekerjaan utama dan pendapatan keluarga. Hasil penelitian menunjukkan bahwa konsumen potensial dari fry counter mempunyai proporsi terbesar dengan usia antara 36 hingga 45 tahun $(35,0 \%)$ dan 46 hingga 55 tahun (32,0\%), berjenis kelamin lakilaki $(93,0 \%)$, berpendidikan tamat SMP $(38,0 \%)$ dan tamat SD $(36,0 \%)$, sudah menikah $(91,0 \%)$, pembenihan sebagai usaha utama $(55,0 \%)$, dan merupakan pemilik sekaligus pengelola dari usaha pembenihan yang dijalankan $(77,0 \%)$.

\section{Hasil Analisis SEM}

Analisis SEM digunakan untuk melihat hubungan antara komponen antarvariabel berdasarkan model kerangka yang telah disusun secara teoritis dan kajian lapangan sebelumnya. Persepsi dan minat pembelian produk fry counter berdasarkan persepsi atribut dan model AIDA yang diterapkan dalam penelitian ini menghipotesiskan adanya hubungan ataupun pengaruh antarvariabel dalam penelitian ini. Hubungan tersebut meliputi hubungan antarvariabel indikator ke variabel laten dan hubungan antarvariabel laten terhadap persepsi dan minat pembelian produk fry counter berdasarkan persepsi atribut dan model AIDA.

Hasil analisis SEM menunjukkan bahwa pengaruh langsung variabel laten lingkungan terhadap variabel laten persepsi atribut ditunjukkan dengan koefisien model $(\mathrm{Y})$ sebesar 0,67 atau sebesar 44,9 persen, sedangkan pengaruh langsung variabel laten pribadi terhadap variabel laten persepsi atribut ditunjukkan dengan koefisien model $(\mathrm{Y})$ sebesar 0,38 atau sebesar 14,4 persen. Pengaruh langsung variabel laten lingkungan terhadap variabel laten kesadaran ditunjukkan dengan koefisien model $(Y)$ sebesar 0,72 atau sebesar 51,8 persen, sedangkan pengaruh langsung variabel laten persepsi atribut terhadap variabel laten kesadaran ditunjukkan dengan koefisien model (Y) sebesar 0,48 atau sebesar 23,0 persen. Pengaruh langsung variabel laten lingkungan terhadap variabel laten ketertarikan ditunjukkan dengan koefisien model $(\mathrm{Y})$ sebesar 

-0,61 atau sebesar 37,2 persen, pengaruh langsung variabel laten pribadi terhadap variabel laten ketertarikan ditunjukkan dengan koefisien model $(\mathrm{\gamma})$ sebesar 0,67 atau sebesar 44,9 persen, dan pengaruh langsung variabel laten kesadaran terhadap variabel laten ketertarikan ditunjukkan dengan koefisien model ( $\mathrm{Y}$ ) sebesar 0,53 atau sebesar 28,1 persen. Pengaruh langsung variabel laten persepsi atribut terhadap variabel laten minat dapat dikatakan memiliki kontribusi tetapi sangat lemah, ditunjukkan dengan koefisien model ( $\mathrm{Y}$ ) sebesar 0,25 atau sebesar 6,3 persen. Pengaruh langsung variabel laten ketertarikan terhadap variabel laten minat jauh lebih tinggi daripada persepsi atribut, ditunjukkan dengan koefisien model $(\mathrm{\gamma})$ sebesar 0,78 atau sebesar 60,8 persen. Adapun faktor muatan (loading faktor) dan koefisien model yang menunjukkan kontribusi masing-masing variabel dapat dilihat pada Gambar 1.

Hasil yang tersaji pada Tabel 2 menunjukkan bahwa indikator-indikator pada variabel laten memiliki nilai-T faktor lebih besar dari nilai kritis (nilai kritis $=1,96$ untuk alpha $=5$ persen). Nilai koefisien faktor muatan seluruhnya memiliki validitas yang baik, yang mana dapat dikatakan variabel indikator secara tepat mampu mengukur model yang dimaksud. Uji reliabilitas yang menjelaskan tingkat konsistensi variabel indikator dilihat dari Construct Reliability (CR) dan Variance Extracted (VE). Variabel indikator pada variabel laten lingkungan, pribadi, ketertarikan, dan minat memiliki reliabilitas yang baik, karena memiliki nilai CR lebih besar dari 0,7. Sementara itu, variabel laten pribadi memiliki nilai VE yang baik karena lebih besar dari 0,50. Pada penelitian ini hanya variabel laten pribadi yang memiliki $C R$ dan VE yang ideal. Hal tersebut menunjukkan bahwa indikator-indikator yang ada pada variabel laten tersebut mampu memberikan informasi yang diinginkan dan dapat dipercaya (diandalkan) dalam memberikan hasil yang relatif sama (konsisten) apabila dilakukan pengukuran kembali. Namun demikian, terdapat juga model yang kurang reliabel, yaitu persepsi atribut, lingkungan, kesadaran, ketertarikan, dan minat. Walaupun nilai CR untuk variabel lingkungan, ketertarikan, dan minat memiliki nilai CR yang lebih besar dari 0,7 , tetapi nilai VE-nya kurang dari 0,50. Hal ini menunjukkan bahwa indikator-indikator yang ada kurang mampu memberikan konsistensi dalam mengukur variabel laten yang dimaksud.

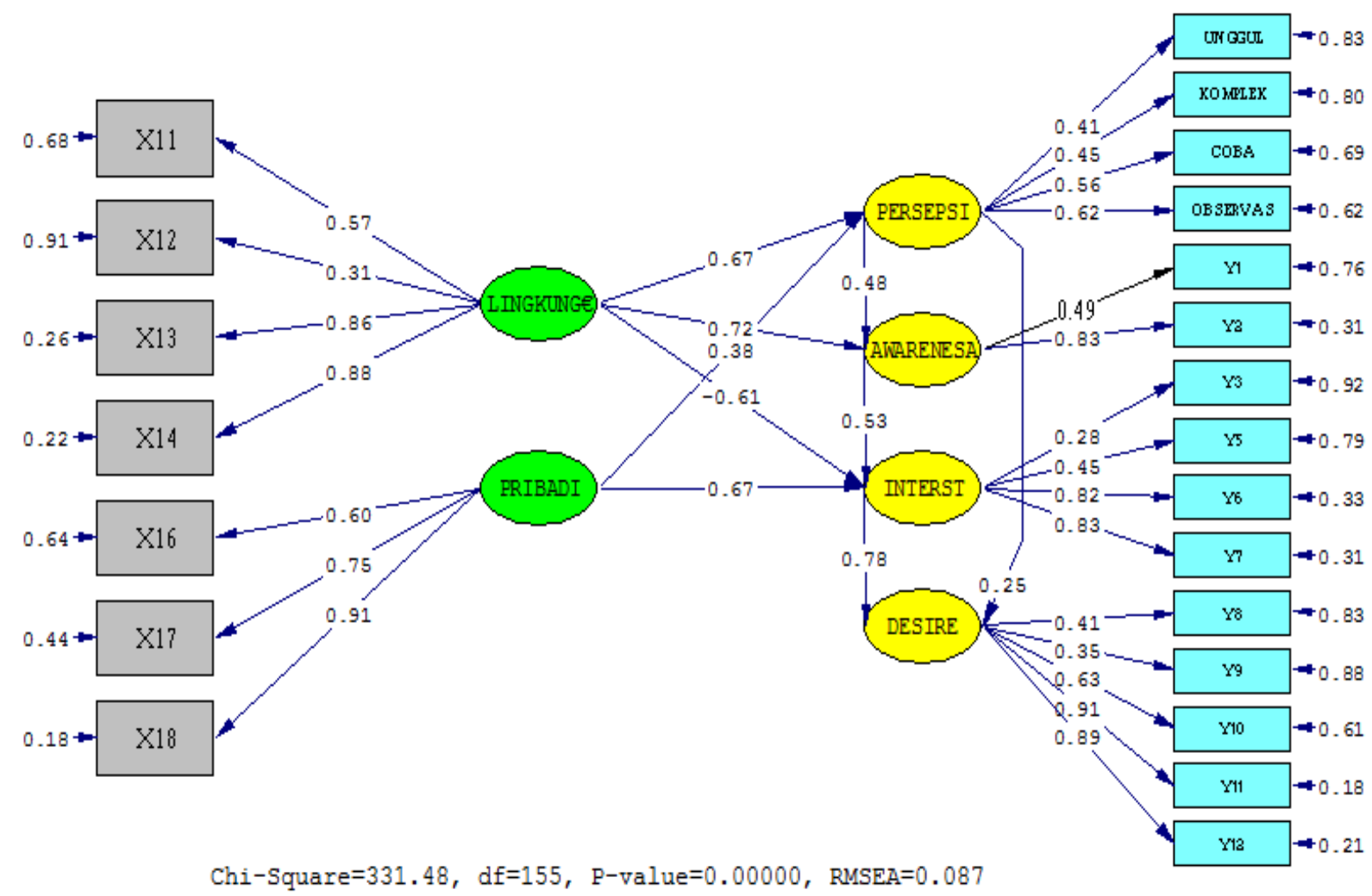

Gambar 1 Faktor muatan dan koefisien model SEM hasil olahan 

Tabel 2 Hasil uji kecocokan model pengukuran

\begin{tabular}{|c|c|c|c|c|c|}
\hline \multirow[b]{2}{*}{ Variabel Indikator } & \multirow[b]{2}{*}{ Variabel Laten } & \multirow[b]{2}{*}{$\begin{array}{c}\text { Faktor } \\
\text { Muatan }\end{array}$} & \multirow[b]{2}{*}{ |T-Hitung $\mid$} & \multicolumn{2}{|c|}{ Realibilitas Konstruk } \\
\hline & & & & $\begin{array}{l}\text { Construct } \\
\text { Reliability }\end{array}$ & $\begin{array}{l}\text { Variance } \\
\text { Extracted }\end{array}$ \\
\hline UNGGUL & \multirow{4}{*}{ PERSEPSI ATRIBUT } & 0,41 & $5,88^{*}$ & \multirow{4}{*}{0,59} & \multirow{4}{*}{0,27} \\
\hline KOMPLEK & & 0,45 & $5,30^{*}$ & & \\
\hline COBA & & 0,56 & $6,46^{*}$ & & \\
\hline OBSERVASI & & 0,62 & $8,33^{*}$ & & \\
\hline $\mathrm{X} 11$ & \multirow{4}{*}{ LINGKUNGAN } & 0,57 & $8,14^{*}$ & \multirow{4}{*}{0,77} & \multirow{4}{*}{0,48} \\
\hline $\mathrm{X} 12$ & & 0,31 & $3,29^{*}$ & & \\
\hline $\mathrm{X} 13$ & & 0,86 & $13,22^{*}$ & & \\
\hline $\mathrm{X} 14$ & & 0,88 & $13,64^{*}$ & & \\
\hline $\mathrm{X} 16$ & \multirow{3}{*}{ PRIBADI } & 0,60 & $8,47^{*}$ & \multirow{3}{*}{0,80} & \multirow{3}{*}{0,58} \\
\hline $\mathrm{X} 17$ & & 0,75 & $10,72^{*}$ & & \\
\hline $\mathrm{X} 18$ & & 0,91 & $13,86^{*}$ & & \\
\hline $\mathrm{Y} 1$ & \multirow{2}{*}{ KESADARAN } & 0,49 & $3,00^{*}$ & \multirow{2}{*}{0,62} & \multirow{2}{*}{0,46} \\
\hline Y2 & & 0,83 & $6,45^{*}$ & & \\
\hline Y3 & \multirow{4}{*}{ KETERTARIKAN } & 0,28 & $3,32^{*}$ & \multirow{4}{*}{0,71} & \multirow{4}{*}{0,41} \\
\hline Y5 & & 0,45 & $5,30^{*}$ & & \\
\hline Y6 & & 0,82 & $7,61^{*}$ & & \\
\hline Y7 & & 0,83 & $7,63^{*}$ & & \\
\hline Y8 & \multirow{5}{*}{ MINAT } & 0,41 & $4,89^{*}$ & \multirow{5}{*}{0,79} & \multirow{5}{*}{0,46} \\
\hline Y9 & & 0,35 & $4,68^{*}$ & & \\
\hline Y10 & & 0,63 & $6,65^{*}$ & & \\
\hline Y11 & & 0,91 & $6,65^{*}$ & & \\
\hline Y12 & & 0,89 & $5,73^{*}$ & & \\
\hline
\end{tabular}

Keterangan: *Signifikan pada alpha $=5 \%$

Selanjutnya, uji kecocokan model struktural dengan hipotesis dilakukan terhadap koefisien persamaan-persamaan struktural dengan mengkhususkan pada tingkat signifikansi tertentu. Pada penelitian ini uji signifikansi menggunakan tingkat signifikansi 0,05 (tingkat kepercayaan 95\%). Oleh karenanya, pada tingkat signifikansi 0,05 nilai-T faktor dari setiap koefisien persamaan struktural harus lebih besar daripada |1,96|. Secara ringkas, rangkuman hasil uji kecocokan model pengukuran dengan hipotesis yang telah dibuat dapat dilihat pada Tabel 3.

Hasil penelitian ini menunjukkan bahwa variabel laten lingkungan dan pribadi memiliki pengaruh langsung terhadap persepsi atribut. Penelitian ini juga menemukan bahwa variabel laten kesadaran dipengaruhi oleh dua variabel laten yaitu variabel laten lingkungan dan persepsi atribut. Kedua variabel laten ini secara nyata pada taraf uji 5 persen mampu menjelaskan bagaimana kontribusi masingmasing tersebut terhadap kesadaran. Pengaruh langsung lingkungan terhadap kesadaran ditunjukkan dengan koefisien sebesar 0,72, sedangkan pengaruh langsung persepsi atribut terhadap kesadaran ditunjukkan dengan koefisien sebesar 0,48 . Sementara itu, variabel laten ketertarikan dibentuk oleh tiga variabel laten yaitu lingkungan, pribadi, dan kesadaran. Ketiga variabel laten ini secara nyata pada taraf uji 5 persen mampu menjelaskan bagaimana kontribusi masing-masing terhadap ketertarikan. Pengaruh langsung lingkungan terhadap variabel laten ketertarikan ditunjukkan dengan koefisien sebesar -0,61, pengaruh langsung pribadi terhadap ketertarikan ditunjukkan dengan koefisien sebesar 0,67, dan pengaruh langsung kesadaran terhadap ketertarikan ditunjukkan dengan koefisien sebesar 0,53 . Selanjutnya, minat konsumen terhadap fry counter secara signifikan dibentuk oleh dua variabel laten yaitu persepsi atribut dan ketertarikan. Kedua variabel laten ini secara nyata pada taraf uji 5 persen mampu menjelaskan bagaimana kontribusi masingmasing variabel laten tersebut terhadap variabel laten keinginan. Pengaruh langsung persepsi atribut terhadap minat yang ditemukan dalam penelitian inidapat dikatakan memiliki kontribusi tetapi sangat lemah, ditunjukkan dengan koefisien sebesar 0,25. Pengaruh langsung ketertarikan terhadap minatjauh lebih tinggi daripada persepsi atribut, ditunjukkan dengan koefisien sebesar 0,78. Pengaruh persepsi atribut walaupun secara koefisien sangat kecil tetapi secara statistik masih melewati nilai-T faktor sebesar 1,96 sehingga dinyatakan masih signifikan. 

Tabel 3 Hasil uji kecocokan model dengan hipotesis

\begin{tabular}{clrrr}
\hline Hipotesis $^{\text {a) }}$ & Pengaruh antar variabel & $\begin{array}{c}\text { Koefisien } \\
\text { konstruk }\end{array}$ & |T-Hitung & Keterangan $^{\text {b) }}$ \\
\hline 1 & Persepsi atribut $\rightarrow$ kesadaran & 0,48 & 5,12 & Signifikan \\
3 & Persepsi atribut $\rightarrow$ minat & 0,25 & 3,35 & Signifikan \\
4 & Lingkungan $\rightarrow$ persepsi atribut & 0,67 & 3,92 & Signifikan \\
5 & Lingkungan $\rightarrow$ kesadaran & 0,72 & 5,54 & Signifikan \\
6 & Lingkungan $\rightarrow$ ketertarikan & $-0,61$ & $-2,61$ & Signifikan \\
8 & Pribadi $\rightarrow$ persepsi atribut & 0,38 & 2,33 & Signifikan \\
10 & Pribadi $\rightarrow$ ketertarikan & 0,67 & 4,05 & Signifikan \\
12 & Kesadaran $\rightarrow$ ketertarikan & 0,53 & 2,54 & Signifikan \\
13 & Ketertarikan $\rightarrow$ minat & 0,78 & 4,68 & Signifikan \\
\hline
\end{tabular}

Keterangan:

a) Hipotesis 2, 7, 9, dan 11 dihilangkan dari jalur karena tidak signifikan danmembuat nilai kesesuaian model SEM menjadi poor/bad fit,

b) Semua variabel laten signifikan pada alpha $=5 \%$

\section{PEMBAHASAN}

Hasil penelitian menunjukkan bahwa lingkungan lebih memberikan pengaruh yang lebih besar daripada pribadi. Temuan ini menegaskan bahwa pembenih ikan dalam penelitian ini mudah dipengaruhi faktor lingkungan dalam menentukan persepsi atribut fry counter. Dalam mengadopsi suatu inovasi terbaru seperti fry counter, responden dalam penelitian ini cenderung melihat dari sisi lingkungannya terlebih dahulu daripada sisi pribadi. Pengaruh rekan usaha, media massa, dan balai penelitian dapat memengaruhi seseorang dalam menerima inovasi terbaru berupa fry counter yang kemudian akan digunakan untuk kemajuan usahanya. Pada umumnya memang sikap dan persepsi responden dipengaruhi oleh pendapat pribadi dari orang-orang yang berada disekitarnya, bahkan peran opinion leader yang memberikan nasihat, saran dan masukan kepada konsumen berpengaruh dalam pengambilan keputusan dalam proses pembelian. Hal ini sejalan dengan hasil penelitian Akhsan (1998), yang mana jika hasrat dan minat konsumen sangat kuat karena rangsangan persuasif dari faktor eksternal maka konsumen akan mengambil keputusan membeli produk yang ditawarkan walaupun produk tersebut masih tergolong asing bagi konsumen tersebut.

Hasil selanjutnya juga menunjukkan adanya perbedaan nilai pengaruh langsung yang cukup jauh antara lingkungan dan persepsi atribut terhadap kesadaran. Hasil penelitian ini menemukan bahwa pengaruh langsung persepsi atribut cukup lemah, walaupun begitu kedua variabel laten tersebut tetap memiliki kontribusi yang signifikan dalam pembentukan kesadaran. Berdasarkan konsep AIDA, proses psikologis yang dilalui oleh konsumen diawali dengan tahap sadar tentang keberadaan produk. Pada kasus fry counter, ternyata faktor utama pembentuk kesadaran adalah faktor lingkungan.

Analisis selanjutnya juga menemukan bahwa lingkungan memiliki nilai koefisien model negatif yang menunjukkan lingkungan dan ketertarikanmemiliki korelasi yang terbalik. Dalam kasus fry counter, peningkatan kontribusi faktor lingkungan justru akan menyebabkan ketertarikan pembenih menjadi menurun. Pembudidaya ikan yang menjadi konsumen dalam penelitian ini menganggap bahwa mereka tidak perlu dipengaruhi oleh lingkungan untuk menciptakan minat terhadap fry counter, mereka sudah terlebih dahulu sadar bahwa sangat penting untuk meng-gunakan fry counter untuk kelangsungan operasional usaha mereka. Jika dikaitkan dengan faktor lain yang membentuk ketertarikan, faktor pribadi dan kesadaran yang timbul lebih kuat memengaruhi konsumen dalam pembentukan ketertarikan.

Berdasarkan nilai koefisien yang diperoleh dalam model, faktor penentu utama dari pembentukan minat terhadap fry counter pada penelitian ini adalah ketertarikan. Oleh karenanya, dalam pemasaran produk fry counter diperlukan pengembangan ketertarikan konsumen pada produk tersebut, apalagi fry counter merupakan produk yang sarat dengan inovasi yang dapat mendukung efisiensi usaha. Pada tahapan interest, aktivitas dari pemasar harus lebih ditingkatkan lagi sehingga dapat menstimulasi minat untuk membeli produk fry counter. Diperlukan suatu promosi intensif yang sebaiknya dilakukan oleh produsen atau pemasar terutama dalam meningkatkan minat adopter sebelum akhirnya dapat diarahkan untuk membeli produk fry counter. Konsumen sebagai adopter menggunakan informasi yang disampaikan oleh produsen dan pemasar untuk 

menciptakan ketertarikan yang kemudian berujung kepada minat pembelian fry counter. Ketika adopter telah mengetahui bahwa produk fry counter ini benar-benar sesuai dengan ekspektasi minat mereka, adopter selanjutnya akan terdorong untuk mengadopsi dan menggunakan fry counter.

Penelitian mengenai adopsi inovasi tidak seluruhnya menyatakan positif bahwa suatu inovasi akan dapat diterima dengan mudah oleh adopter, hal ini dapat disebut sebagai resistensi inovasi. Resitensi terhadap inovasi terjadi jika seorang konsumen merasa terpaksa untuk merubah perilakunya ke arah produk inovatif. Hasil penelitian ini sejalan dengan pernyataan Marakas dan Hornik (1996) pada penelitiannya mengenai perilaku resistensi sebagai sebuah respon untuk menentang dengan adanya sistem baru. Ram dan Seth (1989) dalam penelitiannya mengenai resistensi konsumen terhadap inovasi menyatakan bahwa penolakan atau penundaan adopsi inovasi bukan merupakan sisi sebaliknya dari adopsi inovasi, namun justru bisa dijadikan sebagai anteseden adopsi. Alasannya, bahwa individu biasanya akan mengambil sikap menunda adopsi sebelum benar-benar meng-ambil keputusan untuk mengadopsi. Inovasi produk sifatnya rumit dan lebih sensitif dan berbeda diantara beberapa faktor, meliputi ciri-ciri, kegunaan, dan konektifitas.

Hasil analisis SEM menunjukkan bahwa dalam membentuk minat untuk melakukan pembelian fry counter diawali dari kesadaran ke minat, yang dipengaruhi oleh variabel-variabel lingkungan, pribadi, maupun persepsi konsumen terhadap atribut produk. Dari segi produk, fry counter secara umum memiliki kesesuaian yang baik dalam hal persepsi atribut baik dalam segi keunggulan, kesesuaian, kerumitan, mampu coba, dan mampu observasi. Indikator yang harus diperhatikan memiliki faktor muatan tertinggi dalam pembentukan persepsi atribut adalah kemampuan fry counter untuk diobservasi dari bentuk dan manfaat maupun cara kerja produknya. Selain itu kemudahan untuk dicoba untuk mengetahu cara pemakaian, fungsi, maupun kehandalan merupakan faktor muatan tertinggi berikutnya. Selain itu, untuk meningkatkan keinginan responden akan lebih baik jika para responden diberikan kesempatan untuk mencoba terlebih dahulu karena menjadi indikator dengan faktor muatan tertinggi pada variabel keinginan.

Pembenih ikan berskala kecil umumnya memiliki anggaran yang kecil untuk melakukan penghitungan benih per hari panen produksi benih tersebut yang berkisar antara Rp10.000 hingga $\mathrm{Rp} 50.000$ dengan mayoritas frekuensi penjualan berkisar antara 1-12 kali per tahun atau rata-rata satu kali per bulan. Jika dikaitkan dengan pertanyaan indeks pangsa pasar, segmen yang telah dilakukan penelitian memandang harga fry counter seri 4 sebesar Rp4.500.000,00 memiliki harga yang tidak terjangkau dan harga tersebut dirasakan kurang sesuai dengan manfaatnya. Keter-jangkauan harga merupakan indikator dengan faktor muatan tertinggi kedua dalam membentuk variabel laten keinginan. Dengan demikian, jika ingin melakukan penetrasi produk bagi usaha secara perorangan dapat dilakukan dengan melakukan pengembangan produk dalam versi yang lebih sederhana untuk para pembenih ikan berskala kecil yaitu dengan kriteria kapasitas sekitar 20.000 ekor dengan tingkat harga yang lebih terjangkau. Saat ini, strategi yang dapat diterapkan adalah dengan mengedukasi agar fry counter dapat dibeli secara kelompok-kelompok. Dengan demikian, fry counter tidak akan dirasa terlalu mahal karena dibeli dan digunakan secara bergiliran.

Selain itu, strategi distribusi produk untuk menyalurkan produk sampai ke tangan konsumen akhir memerlukan dukungan pemasaran lebih baik lagi. Usaha pemasaran fry counter yang ada saat ini yang baru menyediakan produk fry counter di BSLT IPB dirasakan oleh para responden menyulitkan jika ingin melakukan pembelian. Jika pembelian diedukasi pada kelompok-kelompok, maka BLST IPB perlu mendorong tenaga pemasar yang ada untuk menjual dan mengadakan secara langsung kepada petani pembenih. Selain itu, pemilihan retailer yang lebih dekat seperti toko perikanan diperlukan untuk lebih mendukung keterjangkauan akses produk fry counter. Dari segi promosi, fry counter sangat memerlukan pengenalan kepada konsumen potensialnya. Tingkat kepedulian terhadap fry counter yang rendah mencerminkan bahwa fry counter sangat asing bagi para pembenih ikan.

Sementara itu, pada variabel laten lingkungan terdapat temuan bahwa variabel dengan kontribusi terkuat adalah keputusan pembelian usaha yang dipengaruhi oleh strategi promosi melalui media massa dan melalui balai maupun penyuluh. Strategi manajerial yang dapat disampaikan kepada produsen dan pemasar fry counter adalah memperkenalkan melalui media massa seperti brosur maupun media cetak lainnya. Hal ini adalah pengenalan awal sehingga dapat terbentuk gambaran awal di benak konsumen potensial. Pada variabel laten kesadaran, 

keuntungan dalam usaha merupakan faktor terpenting di benak konsumen sehingga promosi yang dilakukan sebaiknya menekankan pada keuntungan usaha daripada cara kerjanya. Pada variabel laten pribadi terdapat temuan bahwa konsumen potensial lebih percaya terhadap informasi yang diberikan oleh orang yang pernah menggunakan produk secara langsung dibandingkan informasi lewat iklan. Diperlukan pengaruh tokoh panutan yang dijadikan mitra dalam mengedukasi kepada konsumen potensial. Sebaiknya tokoh panutan sebaiknya diberikan insentif untuk mencoba, diberi pelatihan gratis, dan diberikan potongan harga sehingga produk, cara kerja, dan kegunaan alat dapat dirasakan dan disampaikan kembali secara tepat dan akurat kepada konsumen potensial secara umum. Pihak IPB selaku produsen juga dapat memberikan uji coba produk dengan berkeliling ke para pembudidaya ikan agar dapat langsung merasakan manfaat produk sebelum membeli fry counter.

\section{SIMPULAN DAN SARAN}

Berdasarkan hasil penelitian didapatkan kesimpulan bahwa tidak semua variabel yang diteliti memiliki pengaruh yang signifikan terhadap variabel persepsi atribut dan model AIDA. Setelah dilakukan modifikasi, terdapat tiga ukuran kesesuaian yang berada dalam kategori good fit, sementara dua ukuran kesesuaian berada dalam kategori marginal fit. Variabel persepsi atribut dipengaruhi signifikan oleh kesadaran dan keinginan. Variabel lingkungan terbukti secara signifikan memengaruhi persepsi atribut dan kesadaran, tetapi memiliki korelasi negatif dengan variabel ketertarikan. Variabel pribadi memengaruhi secara signifikan persepsi atribut dan ketertarikan. Sementara itu, variabel kesadaran terbukti membentuk ketertarikan, dan variabel ketertarikan mampu membentuk minat pada penelitian ini.

Adapun saran yang dirumuskan berdasarkan penelitian ini adalah konsumen potensial yang memiliki daya beli produk yang baik perlu didorong untuk meningkatkan minat dengan menguatkan persepsi atribut secara lebih dalam lagi seperti pemberian kesempatan untuk mencoba serta memberi pelatihan dan pendampingan gratis dalam waktu yang lebih lama. Konsumen potensial yang memiliki minat yang sedang hingga besar namun dengan daya beli produk (keterjangkauan harga) yang rendah dapat diberikan stimulus berupa edukasi pembelian secara berkelompok maupun pemberian skema kredit. Sementara itu, konsumen potensial yang memiliki minat yang rendah dan juga daya beli produk (keterjangkauan harga) yang rendah memerlukan upaya lain dari produsen berupa modifikasi fry counter menjadi lebih sederhana lagi, dan juga apabila memungkinkan didorong melalui bantuan pembiayaan oleh dinas setempat.

\section{DAFTAR PUSTAKA}

Akhsan. (1998). Proses adopsi dan difusi inovasi pemberian makanan tambahan bayi di Kabupaten Bogor Jawa Barat (disertasi). Sekolah Pascasarjana, Institut Pertanian Bogor, Bogor.

Azizi, A., \& Hikmah. (2008). Identifikasi faktorfaktor yang memengaruhi pengambilan keputusan dalam pengadopsian paket teknologi budidaya di Tanah Laut Kalimantan Selatan. Jurnal Bijak dan Riset Sosek KP, 3(2), 213-231.

Chaudhuri, A. (1994). The diffusion of an innovation in Indonesia. Journal of Product and Brand Management, 3(3),19-26.

Jaya, I., \& Rahmat, A. (2012). Rencana komersialisasi produk fry counter: High speed and accurate fish counter (penghitung benih ikan kecepatan tinggi). Bogor: Institut Pertanian Bogor.

Kotler, P., \& Armstrong, G. (2008). Prinsipprinsip pemasaran Jilid 1. Ed ke-12. Sabran B, penerjemah. Jakarta, ID: Erlangga.

Marakas, G. M., \& Hornik, S. (1996). Passive resistance misuse: overt support and covert recalcitrance in Is implementation. European Journal of Information Systems, 5(3), 208-219.

Martinez, E., Polo, Y., \& Flavián, C. (1998). The acceptance and diffusion of new consumer durables: Differences between first and last adopters. Journal of Consumer Marketing, 15(4), 323-342.

Pitt, L., Napoli, J., \& Van Der, R. (2003). Managing the franchised brand: The franchisees' perspective. Journal of Brand Management, 10(6), 411-420.

Rahab. (2009). Hubungan antara karakteristik teknologi dengan kemungkinan usaha kecil untuk mengadopsi teknologi informasi. Jurnal Bisnis dan Ekonomi, 16(2), 111125.

Ram, S., \& Sheth, J. N. (1989). Consumer resistance to innovation: The marketing problem and its solutions. Journal of Consumer Marketing, 6(1), 5-14. 

Sandee, H., \& Rietveld, P. (2001). Upgrading traditional technologies in small-scale industry clusters: collaboration and innovation adoption in Indonesia. The Journal of Development Studies, 37(4), 150-172.

Santosa, A.B. (2006). Difusi inovasi marketing mix melalui kelompok usaha sektor informal (upaya peningkatan pemasaran produk sektor formal. Jurnal Eksekutif, 3(1), 53-61.
Soleh, M. (2008). Analisis Strategi Inovasi dan Dampaknya Terhadap Kinerja Perusahaan (Studi Kasus: UKM Manufaktur di Kota Semarang) (tesis). Program Pascasarjana, Universitas Diponegoro, Semarang.

Sumarwan, U. (2011). Perilaku konsumen: Teori dan penerapannya dalam pemasaran. Bogor, ID: Ghalia Indonesia. 